\title{
Trends in cervical cancer mortality in Brazil in 5 years (2012-2016)
}

\author{
Tendências da mortalidade por câncer de colo no Brasil em 5 anos \\ (2012-2016)
}

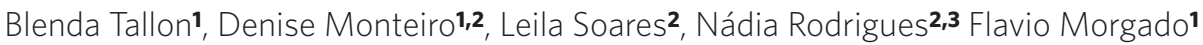

DOI: 10.1590/0103-1104202012506I

\begin{abstract}
Cervical cancer is an important cause of death in Brazil. The aim of this study is to find out the mortality rate due to this cancer in the female population, between 2012 and 2016, knowing the mortality in the age groups and in the different regions. A descriptive cross-sectional study was carried out. Data were obtained using the Mortality Information System. Between 2012 and 2016, the total number of deaths due to cervical cancer was 27.716 cases. The specific mortality rate for Brazil went from 6,86 to 7,18 . The growth of the mortality coefficient was $4.6 \%$. In women under 25 years of age, 189 deaths were observed, equivalent to $0.68 \%$ of the total. Between 25 and 64 years, there were 18.574 deaths (67.02\%) and 8.950 deaths in the group over 64 years (32.29\%). The highest percentage of deaths occurred in the 50-54 age group. The North region had the highest death rates, and the South, the highest growth rate. Cervical cancer mortality in Brazil increased during the years observed, with more deaths between 50-54 years. The South region showed the highest growth in mortality rates.
\end{abstract}

KEYWORDS Uterine cervical neoplasms. Neoplasms. Mortality.

RESUMO O câncer do colo uterino é uma importante causa de morte no Brasil. O objetivo deste estudo é avaliar a mortalidade por esse câncer na população brasileira, entre 2012 e 2016, conhecendo a mortalidade nos grupos etários e nas diferentes regiões. Foi realizado um estudo de corte transversal descritivo. Os dados foram obtidos pelo Sistema de Informações sobre Mortalidade. Entre 2012 e 2016, o total de óbitos por câncer do colo do útero foi de 27.716 casos. A taxa de mortalidade específica para o Brasil passou de 6,86 para 7,18. O crescimento do coeficiente de mortalidade foi de 4,6\%. Nas mulheres abaixo de 25 anos, observaram-se 189 mortes, o que equivale a 0,68\% do total. Entre 25 e 64 anos, houve 18.574 óbitos (67,02\%), e 8.950 mortes no grupo acima de 64 anos (32,29\%). O maior percentual de óbitos ocorreu na faixa etária de 50-54 anos. A região Norte apresentou os maiores índices de óbitos e taxas de mortalidade, e o Sul o maior índice de crescimento. A mortalidade por câncer do colo uterino no Brasil apresentou crescimento durante os anos observados, com mais óbitos entre 50-54 anos. A região Sul apresentou o maior crescimento nas taxas de mortalidade.

1 Centro Universitário Serra dos Órgãos (Unifeso) Teresópolis (RJ), Brasil.

2 Universidade do Estado do Rio de Janeiro (Uerj) Rio de Janeiro (RJ), Brasil. Ics1507@yahoo.com.br

3 Fundação Oswaldo Cruz (Fiocruz), Escola Naciona de Saúde Pública Sergio Arouca (Ensp) - Rio de Janeiro (RJ), Brasil.
PALAVRAS-CHAVE Neoplasias do colo do útero. Neoplasmas. Mortalidade. 


\section{Introduction}

In the ranking of cancer causes in the female population of Brazil, cervical cancer ranks third, not considering non-melanoma skin cancer, second only to breast cancer and colorectal cancer. With regard to cancer mortality in the Country, this neoplasm ranks fourth among women'.

Cervical cancer is the fourth most incident in the female population worldwide, with approximately 530.000 new cases per year worldwide, and it is also the fourth in relation to mortality ${ }^{2,3}$. The estimate for 2018 was 311.365 deaths worldwide ${ }^{3}$. Areas with the lowest levels of development have the highest incidence rates ${ }^{\mathbf{4}, 5}$.

Most cervical cancer cases are related to Human Papillomavirus (HPV) infection ${ }^{6}$. There are several types of HPV. Among oncogenic ones, 16 and 18 stand out, responsible for $60 \%$ and $15 \%$ of cases of cervical cancer, respectively ${ }^{7}$. Infection with this virus is the most frequent sexually transmitted infection in the world, and the majority of the sexually active population will have contact with the agent at some point in life ${ }^{8}$. For the development of precursor lesions and cervical cancer itself, it is necessary the development of a persistent infection ${ }^{\mathbf{1}, \mathbf{7}}$. Other risk factors influence this evolution, such as age over 30 years, in which persistence is more frequent ${ }^{7}$.

Primary prevention consists of reducing the HPV contagion through the use of condoms and vaccination. The strategy for secondary prevention is screening and early diagnosis, which are essential to ensure that the chance of cure is $100 \%$ in the early stages ${ }^{1}$.

Screening is performed with cytopathological analysis, which contributes to the reduction of disease incidence and mortality rates ${ }^{4,9}$. The improvement of such indicators has not been observed in countries with low economic development, reflecting the difficulties in access to health ${ }^{4}$. The higher the coverage and the more organized the screening program, the greater the effectiveness ${ }^{7,9}$. In countries that reach coverage above $70 \%$, the mortality rate is low (less than or equal to two deaths per 100 thousand women per year). According to the Brazilian Guidelines for the screening of cervical cancer, screening should be performed in women aged between 25 and 64 years, and, after two annual exams without changes, it can be performed every three years ${ }^{9}$.

The quadrivalent HPV vaccine was introduced in the National Immunization Program in Brazil in 2014. The low uptake that occurred was attributed to fear of adverse reactions, hesitation of the vaccine by parents and logistical challenges ${ }^{\mathbf{1 0}}$. Furthermore, the 2011-2022 Plan for Coping with Chronic Diseases established a target of $85 \%$ for the coverage of the Pap test, however, several studies have observed lower coverage among women with greater social vulnerability, especially in the poorest regions of the Ccountry ${ }^{11}$.

According to the National Cancer Institute José Alencar Gomes da Silva (Inca), 16.370 new cases of cervical cancer are estimated and a risk of 15,43 cases per 100 thousand women for the years between 2018-2019, in Brazil. Thus, this disease remains in the third position in incidence ${ }^{\mathbf{1 2}}$.

According to estimates for the years between 2018-2019, the highest incidence of cervical cancer persists in the Center-west, Northeast and North regions in relation to other regions. In the North, it is the first most incident, with a rate of 25,62 cases for every 100 thousand women per year, an indicator that can be compared to one of the regions with the highest risk, North Africa (30,6/100 thousand) ${ }^{\mathbf{1 2}}$.

The aim of this work is to observe the number of deaths and mortality rates due to cervical cancer in the female population of Brazil. 


\section{Material and methods}

This is a cross-sectional study, carried out between the years 2012 and 2016. The population was divided into age groups every 5 years in the different Brazilian regions. The publication called the Mortality Atlas of the Ministry of Health/Inca was used as the basis, in which the youngest age at which death from cervical cancer occurred was 15 years old, and the last age range evaluated includes women aged 80 years and over ${ }^{13}$.

Information on the number of deaths was obtained by accessing the Mortality Information System (SIM) ${ }^{\mathbf{1 4}}$. SIM is one of the components of the Health Information System. It was created by the Brazilian Health Informatics Department (Datasus) and uses the Death Certificate as an information source. This system is useful for capturing mortality data and can serve to guide public health planning and actions. Some problems interfere with the quality of the data, such as underreporting and the percentage of deaths with ill-defined causes5,15.

The estimate of the female population, divided into age group in five-years groups, was obtained through the Federation Units Population Projection by sex and age groups: 2000-2030, from the Brazilian Institute of Geography and Statistics (IBGE) ${ }^{16}$, also available on Datasus.

The specific mortality rate for Brazil was calculated by the ratio of the total number of deaths from this neoplasm to the estimated female population studied, each year. The same calculation was also applied for geographic regions, using the number of deaths per region as the numerator and the population estimate for each region between 2012 and 2016 as the denominator for the female population, object of the study.

The specific mortality rate was calculated by the ratio between the number of deaths for each age group and the estimated population of each age group, per year. In the calculations of all tables, the coefficients were multiplied by the constant 100.000 .

Tables, graphs and statistical analysis were generated by the Microsoft Excel 2016 program.

\section{Results}

Between 2012 and 2016, the total number of deaths from cervical cancer was 27,716 cases, already reported from 15 years of age. There is an increase in the absolute number of deaths within the analyzed period. In 2012, 5.264 deaths were recorded, a number that increased to 5.847 deaths in 2016 (table 1).

The calculation of the specific mortality rate for Brazil in the age group and in the studied period went from 6,86 to 7,18 (table 1). Over the analyzed years, 21 deaths occurred between $15-19$ years old, representing $0.08 \%$ of the total and 168 between $20-24$ years old (0.61\%). In the ages between 25 and 64 years, where screening is recommended, there were 18.574 deaths $(67.02 \%)$, with the highest percentage of deaths (11.52\%) in the 50-54 age group.

In women below 25 years of age, who are not at the age of cervical cancer screening, according to the Brazilian Guidelines for cervical cancer screening9, 189 deaths were observed, which is equivalent to $0.69 \%$ of the total. In addition, there were 8.950 deaths in the group of women over 64 years of age, who are also outside the screening age group?, corresponding to almost a third of the total deaths (32.29\%). 
Table 1. Specific mortality rate* due to cervical cancer, by Brazilian regions, for the female population by age group, between 2012 and 2016

\begin{tabular}{|c|c|c|c|c|c|c|c|c|c|c|c|c|}
\hline \multirow[t]{2}{*}{ Age range } & \multicolumn{2}{|l|}{2012} & \multicolumn{2}{|l|}{2013} & \multicolumn{2}{|l|}{2014} & \multicolumn{2}{|c|}{2015} & \multicolumn{2}{|l|}{2016} & \multirow{2}{*}{$\begin{array}{l}\text { Total of } \\
\text { deaths }\end{array}$} & \multirow{2}{*}{$\begin{array}{r}\% \text { of tota } \\
\text { deaths }\end{array}$} \\
\hline & № of deaths & Rate & № of deaths & Rate & № of deaths & Rate & № of deaths & Rate & № of deaths & $\overline{\text { Rate }}$ & & \\
\hline $15-19$ & 5 & 0.06 & 5 & 0.06 & 5 & 0.06 & 1 & 0.01 & 5 & 0.06 & 21 & $0.08 \%$ \\
\hline $20-24$ & 40 & 0.47 & 29 & 0.34 & 29 & 0.34 & 33 & 0.39 & 37 & 0.44 & 168 & $0.61 \%$ \\
\hline $25-29$ & 129 & 0.45 & 125 & 0.33 & 118 & 0.34 & 125 & 0.39 & 124 & 0.44 & 621 & $2.24 \%$ \\
\hline $30-34$ & 226 & 1.53 & 278 & 1.45 & 288 & 3.29 & 330 & 3.74 & 303 & 1.40 & 1425 & $5.14 \%$ \\
\hline $35-39$ & 397 & 3.04 & 363 & 3.66 & 421 & 3.70 & 424 & 4.14 & 466 & 3.71 & 2071 & $7.47 \%$ \\
\hline $40-44$ & 467 & 5.87 & 492 & 5.30 & 472 & 6.07 & 518 & 6.00 & 515 & 6.47 & 2464 & $8.89 \%$ \\
\hline $45-49$ & 625 & 7.38 & 582 & 7.69 & 557 & 8.61 & 580 & 8.87 & 655 & 7.79 & 2999 & $10.82 \%$ \\
\hline $50-54$ & 587 & 11.17 & 631 & 10.11 & 635 & 10.76 & 648 & 10.75 & 691 & 10.68 & 3192 & $11.52 \%$ \\
\hline $55-59$ & 562 & 12.66 & 624 & 13.15 & 581 & 11.72 & 634 & 12.38 & 632 & 13.08 & 3033 & $10.94 \%$ \\
\hline $60-64$ & 527 & 15.27 & 521 & 16.28 & 579 & 14.58 & 568 & 15.31 & 574 & 14.70 & 2769 & $9.99 \%$ \\
\hline $65-69$ & 470 & 17.09 & 487 & 16.87 & 499 & 16.47 & 545 & 17.18 & 487 & 14.68 & 2488 & $8.98 \%$ \\
\hline $70-74$ & 414 & 19.84 & 425 & 19.88 & 395 & 17.95 & 421 & 18.44 & 448 & 18.81 & 2103 & $7.59 \%$ \\
\hline $75-79$ & 326 & 21.55 & 372 & 23.61 & 351 & 21.45 & 373 & 22.05 & 371 & 21.29 & 1793 & $6.47 \%$ \\
\hline 80 or more & 488 & 26.95 & 496 & 26.25 & 518 & 26.25 & 526 & 25.51 & 538 & 24.94 & 2566 & $9.26 \%$ \\
\hline Unknown age & 1 & 0.00 & 0 & 0.00 & 0 & 0.00 & 1 & 0.00 & 1 & 0.00 & 3 & $0.01 \%$ \\
\hline Total & 5264 & 6.86 & 5430 & 6.97 & 5448 & 6.88 & 5727 & 7.13 & 5847 & 7.18 & 27716 & \\
\hline
\end{tabular}

${ }^{*}$ Specific mortality rate $=n^{\circ}$ of deaths in the age group/female population in the same age group. Mortality Information System ${ }^{11}$, Population Projections of the Federation Units by sex and age groups: 2000-203014.

Although the above 64-year-old group concentrated an important portion of the mortality rate (table 1), it presented the highest percentage decreases of the coefficients between 2012 and 2016 (graph1). In addition, it is noted that the mortality rate calculated for the age group between 30-34 years presented the highest percentage increase between the five years (27.99\%).

Graph 1. Percentage growth of cervical cancer mortality rates by Brazilian region, for the female population aged 15 and over, between 2012-2016

Growth between 2012-2016

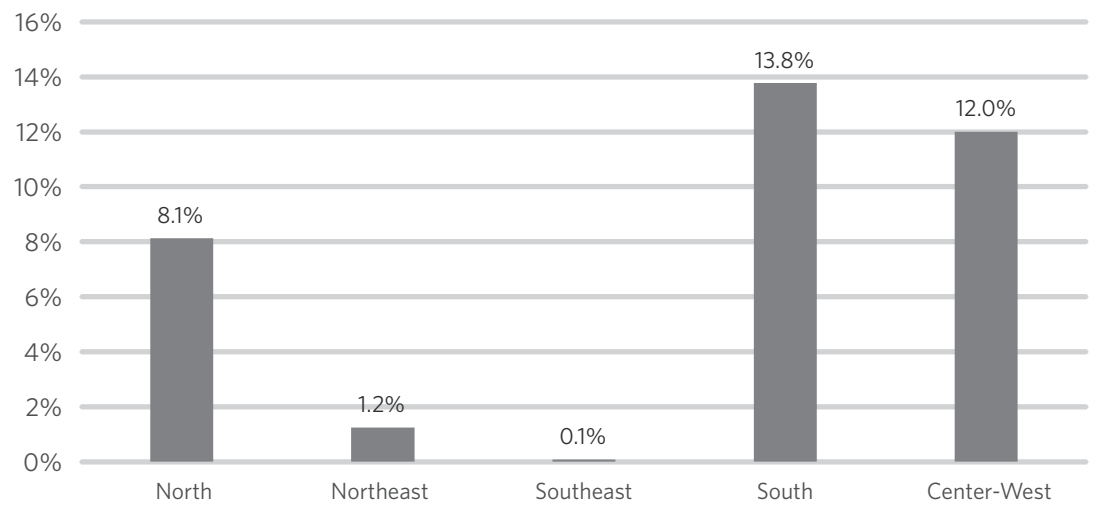


Regarding the Brazilian regions in the period considered, all of them showed an increase in the absolute number of deaths, except the South region, which presented a decrease between 2012 and 2014, with a subsequent increase (table 2).

With regard to mortality rates, the North region showed the highest values in all the years considered. This region and also the Centerwest region were the only ones to present increasing mortality rates, with percentage increases of $7.05 \%$ and $1.02 \%$ (North), and $3.59 \%$ and 8.04\% (Center-west), between 2012-2014 and 2014-2016, respectively (table 2).

The Northeast region presented an increase in the mortality rate in the first analyzed period, but a reduction of $0.61 \%$ was observed from 2014 to 2016. Mortality rates in the Southeast and South regions showed similar behavior, with a reduction of $2.64 \%$ (Southeast region) and $4.70 \%$ (South region) between 2012 and 2014 being first noticed. Subsequently, between 2014-2016, the mortality rate in the Southeast region increased by $2.71 \%$, returning to the value found in 2012, and the rate in the South region increased by $19.27 \%$.

The analysis of the percentage variation in mortality rates by Brazilian regions, covering the years 2012 and 2016, also revealed different values, with the South region presenting the highest growth, of $13.66 \%$, followed by the Center-west $(11,93 \%)$ and North regions (8.14\%) (table 2). The Northeast region grew by only $1.23 \%$, and the rates in the Southeast region did not show a percentage change in the period in question (table 2).

Table 2. Specific mortality rate* due to cervical cancer, by Brazilian regions, for the female population aged 15 and over, between 2012 and 2016

\begin{tabular}{|c|c|c|c|c|c|c|c|c|c|}
\hline \multirow[t]{2}{*}{ Regions } & \multicolumn{2}{|c|}{2012} & \multicolumn{2}{|l|}{2014} & \multirow{2}{*}{$\begin{array}{c}\% \text { Change } \\
2012-2014\end{array}$} & \multicolumn{2}{|c|}{2016} & \multirow{2}{*}{$\begin{array}{r}\% \text { Change } \\
2014-2016\end{array}$} & \multirow{2}{*}{$\begin{array}{l}\% \text { Change } \\
2012-2016\end{array}$} \\
\hline & № of deaths & Rate & № of deaths & Rate & & № of deaths & $\begin{array}{l}\text { Rate } \\
\text { nat }\end{array}$ & & \\
\hline North & 673 & 11.92 & 756 & 12.76 & $7.05 \%$ & 800 & 12.89 & $1.02 \%$ & $8.14 \%$ \\
\hline Northeast & 1678 & 8.11 & 1762 & 8.26 & $1.85 \%$ & 1802 & 8.21 & $-0.61 \%$ & $1.23 \%$ \\
\hline Southeast & 1774 & 5.31 & 1774 & 5.17 & $-2.64 \%$ & 1871 & 5.31 & $2.71 \%$ & $0 \%$ \\
\hline South & 748 & 6.59 & 733 & 6.28 & $-4.70 \%$ & 897 & 7.49 & $19.27 \%$ & $13.66 \%$ \\
\hline Center-West & 391 & 6.96 & 423 & 7.21 & $3.59 \%$ & 477 & 7.79 & $8.04 \%$ & $11.93 \%$ \\
\hline Total & 5264 & 6.86 & 5448 & 6.88 & 5727 & 5847 & 7.18 & 27716 & \\
\hline
\end{tabular}

*Specific mortality rate $=\mathrm{n}$ ㅇ of deaths in the region/female population aged 15 and over by region. Mortality Information System ${ }^{\mathbf{1 1}}$ Population Projections of the Federation Units by sex and age groups: 2000-203014

When analyzing the age groups divided according to the recommendations for cervical cancer screening in Brazil9, the variations in the number of deaths and mortality rates between Brazilian regions become clearer. It is possible to notice that all regions presented in the two variables observed for the age of 25 to 64 years from 2012 to 2016 (table 3). The region that showed the greatest increase in the mortality rate was the Center-west (16\%), followed by South (13\%), North (7\%). Southeast (3\%) and Northeast (1\%).
In the group over 64 years old, the increase in the mortality rate was $5 \%$ in the South and $2 \%$ in the North, showing a reduction in the other Brazilian regions between 7 and 15\%.

Due to the small number of cases of deaths from cervical cancer in the young group, up to 24 years of age, the evaluation of the mortality rate showed results with wide variability patterns, including a $63 \%$ reduction to an increase from 40 to $188 \%$, in the different regions (table 3). 
Table 3. Specific mortality rate* due to cervical cancer, by Brazilian regions, for the female population by age group, between 2012 and 2016

\begin{tabular}{|c|c|c|c|c|c|c|}
\hline \multirow[t]{2}{*}{ Region } & \multirow[t]{2}{*}{ Age } & \multicolumn{2}{|c|}{2012} & \multicolumn{2}{|c|}{2016} & \multirow[t]{2}{*}{$\%$ Change } \\
\hline & & № of deaths & Rate & № of deaths & Rate & \\
\hline \multirow[t]{3}{*}{ North } & $<25$ years & 8 & 0.49 & 3 & 0.18 & $-63 \%$ \\
\hline & 25 a 64 years & 471 & 12.86 & 561 & 13.71 & $7 \%$ \\
\hline & $>64$ years & 194 & 53.71 & 236 & 54.57 & $2 \%$ \\
\hline \multirow[t]{3}{*}{ Northeast } & $<25$ years & 16 & 0.32 & 14 & 0.29 & $-9 \%$ \\
\hline & 25-64 years & 1107 & 8.11 & 1202 & 8.18 & $1 \%$ \\
\hline & $>64$ years & 554 & 26.56 & 585 & 24.58 & $-7 \%$ \\
\hline \multirow[t]{3}{*}{ Southeast } & $<25$ years & 10 & 0.15 & 14 & 0.21 & $40 \%$ \\
\hline & 25-64 years & 1158 & 5.07 & 1247 & 5.21 & $3 \%$ \\
\hline & $>64$ years & 606 & 15.48 & 610 & 13.19 & $-15 \%$ \\
\hline \multirow[t]{3}{*}{ South } & $<25$ years & 10 & 0.43 & 8 & 0.35 & $-19 \%$ \\
\hline & $25-64$ years & 517 & 6.73 & 612 & 7.58 & $13 \%$ \\
\hline & $>64$ years & 221 & 16.44 & 277 & 17.32 & $5 \%$ \\
\hline \multirow[t]{3}{*}{ Center-West } & $<25$ years & 1 & 0.08 & 3 & 0.23 & $188 \%$ \\
\hline & 25-64 years & 267 & 6.92 & 338 & 8 & $16 \%$ \\
\hline & $>64$ years & 123 & 27.12 & 136 & 24.13 & $-11 \%$ \\
\hline
\end{tabular}

*Specific mortality rate $=$ no of deaths in the region/female population aged 15 and over. Mortality Information System"1, Population

Projections of the Federation Units by sex and age groups: 2000-203014.

\section{Discussion}

In the present study, there was an increase in the number of deaths due to cervical cancer and in the mortality rates, results that could be expected, since cervical cancer is still a very common disease in low and middle income countries ${ }^{4,5}$. Fedrizzi \& Ponce ${ }^{\mathbf{6}}$, when evaluating mortality between the years 20062014, in women aged 25-64 years, also found an increasing trend for mortality rates and a percentage increase of $19.35 \%$ for the absolute number of deaths.

However, studies that evaluated mortality from cervical cancer in Brazil in previous periods (1980-2010 and 2003-2012) found a decrease in mortality rates 4,5 . The authors justify these results as a reflection of efforts and investments of the Country in policies and programs to control this disease, which began in the $1940 s^{4,5,9}$. Studies carried out in South Korea, between 1993-2012, and in Mexico, between 2000-2010, also observed a reduction in the incidence and mortality due to cervical cancer ${ }^{17,18}$.

On the other hand, a study carried out in the state of Rio Grande do Sul, between 2011-2012, in the group of women aged 25-64 years, found coverage of the Pap test of approximately $17.3 \%{ }^{19}$. Another study carried out between the years 2006-2014, in women aged 25-64 years, in Brazil, observed a decrease in the number of preventive exams performed and, consequently, a decrease in the coverage of the screening, with an average of $16.09 \%^{6}$, which may justify results that point to a decrease in mortality rates. These values show coverage rates much lower than those found in countries with low occurrence of deaths from cervical cancer' ${ }^{9}$.

The time taken between infection with an oncogenic HPV type and the development of invasive disease is long, and the literature shows an increase in the occurrence of cancer with advancing age ${ }^{7}$. In this study, the age group of 50-54 years is the one that covers the 
highest percentage of deaths, confirming the findings of another Brazilian study ${ }^{6}$. In addition, this study found an important mortality coefficient for the age groups above 64 years and a significant percentage in relation to the total number of deaths, despite the fact that they presented the lowest percentage growth between 2012-2016. Likewise, Vale et al.5, when studying mortality from cervical cancer, between 2003-2012, observed an increase in mortality at more advanced ages, with the highest rates above 70 years, however, they observed a tendency to decrease rates from the age of 40 .

According to the American recommendations for screening, it should be performed until the age of 65 or over, and can be extended for 20 years, if necessary ${ }^{7}$. A study carried out with women over 75 years of age with cervical cancer, in Australia, between 1998-2010, found good results regarding survival and treatment tolerance, both for the group with curative treatment and for palliative treatment ${ }^{20}$. In elderly women, most cases of cervical cancer are diagnosed in advanced stages, and in both younger and older age groups the majority of diagnosed cases occur in women without adequate screening?. Observational case-control studies carried out in the USA, United Kingdom, Finland, Sweden, Italy and South Africa showed a reduced risk of cervical cancer in women who underwent screening over 65 years, with a protective effect from 1 to 5 years. However, Pap tests in women over 65 years of age have high physical, emotional and financial costs, in addition to the uncertain benefit of discovering injuries that may never become clinically significant during a woman's life ${ }^{21}$.

In this study, 189 deaths were observed in women under 25 years of age, which is equivalent to $0.68 \%$ of the total deaths from cervical cancer in the analyzed period. Other studies have also found low values, with no statistical value $e^{5,6,17,18}$. These results are also found in the literature, which supports the recommendations to avoid screening in this age group in Brazil9. American guidelines recommend beginning screening at age $21^{7}$.

It is believed that cervical cancer has a more aggressive behavior in young women, and that screening is not as effective in this group, and may arise during screening intervals and, therefore, may generate more risks than benefits $\mathbf{7 , 9 , 2 2}$. Pelkofski et al. ${ }^{23}$ compared 114 women with cervical cancer under 25 years old (17 cases) with the group between 26 and 35 years old ( 97 cases), in the states of Virginia and North Carolina, in the United States of America, and concluded that the progression and survival outcomes are independent of age in women with cervical cancer before or up to 35 years of age, not finding statistical significance to prove a worse prognosis, which depends on the tumor histology, parametrial involvement and staging. Subsequent studies of a young cohort with a higher number of cases may produce different results.

Another relevant finding was found by Balmant et al. ${ }^{24}$, when analyzing neoplasmsrelated mortality between $15-29$ years in Brazil, identifying cervical cancer as the main cause of death in the 25-29 age group. In the present study, the highest percentage increase in deaths between 2012-2016 occurred in the age group of 30-34 years, ages included in the age range where screening is indicated. Considering the natural history of the disease in question, the fact that HPV is the most frequent sexually transmitted infection in the world, especially among young people, and data on mortality in this age group, it can be suggested that the values are not negligible ${ }^{7,8}$. In addition, data that also draw attention in the study by Pelkofski et al. ${ }^{23}$ show that more than $2 \%$ of young women had small cell carcinoma of the cervix, a more aggressive subtype, and approximately $30 \%$ of cases of cervical cancer, in the group under 25 , they occurred at an age of less than or equal to 20 years, although the sample studied was small.

Regarding Brazilian regions, differences between the number of deaths and mortality rates for the years 2012, 2014 and 2016 were 
observed. The North region was the one with the highest number of deaths and mortality rates, results also found in several studies ${ }^{4-6,221}$. Such results are consistent with the Inca's estimates for the 2018-2019 biennium, with cervical cancer being the most prevalent in the North, surpassing breast cancer ${ }^{\mathbf{1 2}}$.

Girianelli et al. 4 found decreasing mortality rates in the states of the North and Northeast regions, however, they detected an increase in municipalities within such localities, and for more developed regions, such as the South and Southeast, they found a trend towards declining cervical cancer mortality rates. It can be inferred, therefore, that the differences between the quality of access to health care in Brazilian regions are still present, corroborating the fact that cervical cancer is more frequent in regions with lower socioeconomic conditions $\mathbf{4}^{\mathbf{4} 5,12}$. However, the increase in mortality in the North region may be one of the reasons for the improvement in the quality of information on deaths, since deaths from illdefined causes decreased during the years 2003-20125. From this, it can be suggested that the percentage growth found in this study for the South region may be due to the higher notification of cases of death and the lower underreporting, already expected for this region due to its better socioeconomic development ${ }^{4,5}$.

The mortality rate in the age group included in the screening increased in all Brazilian regions, with the Center-west as the region with the highest increase in the rates (16\%).

In this study, some weaknesses can be highlighted, as correction methods were not used to include the proportions of deaths from illdefined causes or from malignant neoplasm of the uterus, unspecified portion, which may have even higher values, as found by Vale et al. ${ }^{5}$. In addition, factors that restrict the interpretation of results can be emphasized, such as the lack of an analysis based on some statistical method, the short period of time analyzed and the lack of more recent data.

Another limitation would be the source used for data collection, SIM, whose quality is classified as average. Despite the improvements regarding the quality of information ${ }^{\mathbf{1 2}}$, this can be affected by underreporting and the percentage of deaths with poorly defined causes.

\section{Conclusions}

Cervical cancer mortality in Brazil increased during the years observed, with a higher percentage of deaths in the 50-54-year age group. Deaths were also observed in women who are not included in the recommendations for screening this neoplasm in Brazil. With regard to the Brazilian regions, variations were already expected, due to the heterogeneity of these localities, with the South region presenting the highest percentage increase of specific mortality rates. From the results found, it can be noticed that the control of cervical cancer is still a challenge, demonstrating the need for improvements in prevention programs.

\section{Collaborators}

Tallon B (0000-0003-0668-8574)* developed the study design and method, evaluated the data, participated in the preparation of the results and wrote the manuscript. Monteiro D (0000-0003-4679-1859)* developed the study design and method, evaluated the data, participated in the preparation of the results, wrote and edited the manuscript. Soares L (0000-0001-8360-3189)* wrote and edited the manuscript. Rodrigues N (0000-0002-2613$5283) *$ evaluated the data and participated in the elaboration of the results. Morgado F (0000-0002-8199-3934)* developed the study design and method, evaluated the data and participated in the preparation of the results. All authors read and approved the final edition of the manuscript.
*Orcid (Open Researcher and Contributor ID). 


\section{References}

1. Instituto Nacional de Câncer José Alencar Gomes da Silva. Diretrizes brasileiras para o rastreamento do câncer do colo do útero: Atualização 2016. Rio de Janeiro: INCA; 2016. [acesso em 2016 out 3]. Disponível em: https://www.inca.gov.br/tipos-de-cancer/ cancer-do-colo-do-utero.

2. World Health Organization. International Agency for Research on Cancer. Estimated number of new cases in 2018, worldwide, females, all ages [internet]. [acesso em 2018 out 10]. Disponível em: https://gco.iarc.fr/today/online-analysis-table $? \mathrm{v}=2018 \&$ mode $=$ cancer $\&$ mode_popula tion $=$ continents $\&$ population $=900 \&$ populations $=$ $900 \&$ key $=$ asr $\&$ sex $=2 \&$ cancer $=39 \&$ type $=0 \&$ statis tic $=5 \&$ prevalence $=0 \&$ population_group $=0 \&$ ages group $\% 5 \mathrm{~B} \% 5 \mathrm{D}=0 \&$ ages_group $\% 5 \mathrm{~B} \% 5 \mathrm{D}=17 \& \mathrm{nb}$ items=5\&group_cancer=1\&include_nmsc $=1 \&$ include_ nmsc_other $=1$.

3. World Health Organization. International Agency for Research on Cancer. Estimated number of deaths in 2018, worldwide, females, all ages [internet]. [acesso em 2018 out 10]. Disponível em: https://gco. iarc.fr/today/online-analysis-table? $\mathrm{v}=2018 \&$ mode $=$ cancer\&mode_population $=$ continents\&populatio $\mathrm{n}=900 \&$ populations $=900 \& \mathrm{key}=\mathrm{asr} \& \mathrm{sex}=2 \& \mathrm{can}$ cer $=39 \&$ type $=1 \&$ statistic $=5 \&$ prevalence $=0 \&$ pop ulation_group $=0 \&$ ages_group $\% 5 \mathrm{~B} \% 5 \mathrm{D}=0$ \&ages_ group \% 5 B \% 5 = 17\& nb_items $=5 \&$ group cancer=1\&include_nmsc=1\&include_nmsc_other $=1$.

4. Girianelli VR, Gamarra CJ, Silva GA. Disparities in cervical and breast cancer mortality in Brazil. Rev. Saúde Pública. 2014; 48(3):459-67.

5. Vale DB, Sauvaget C, Muwonge R, Ferlay J, et al. Disparities in time trends of cervical cancer mortality rates in Brazil. Cancer Causes Control. 2016; 27(7):889-96.

6. Fedrizzi EN, Ponce NM. Coverage of pap smear and mortality from cervical cancer in Brazil from 2006 to 2014. DST - J. Bras. Doenças Sex. Transm. 2017; 29(4):117-24.
7. The American College of Obstetricians and Gynecologists (ACOG) - ACOG Committee on Practice Bulletins - Gynecology. ACOG Practice Bulletin Number 168: Cervical cancer screening and prevention. Obstet. Gynecol. 2016; 128(4):111-30.

8. Centers for Disease Control and Prevention. Human papillomavirus (HPV) [internet]. [acesso em 2018 out 5]. Disponível em: https://www.cdc.gov/std/hpv/ stdfact-hpv.htm

9. Instituto Nacional de Câncer José Alencar Gomes da Silva. Diretrizes brasileiras para o rastreamento do câncer do colo do útero [internet]. Brasília, DF: Ministério da Saúde; 2016 [acesso em 2018 out 5]; 118 p. Disponível em: http://wwwl.inca.gov.br/inca/Arquivos/DDiretrizes_para_o_Rastreamento_do_cancer_do_colo_do_utero_2016_corrigido.pdf.

10. Lobão WM, Duarte FG, Burns JD, et al. Low coverage of HPV vaccination in the national immunization programme in Brazil: Parental vaccine refusal or barriers in health-service based vaccine delivery? PloS one. 2018; 13(11):e0206726.

11. Barcelos MRB, Lima RCD, Tomasi E, et al. Qualidade do rastreamento do câncer de colo uterino no Brasil: avaliação externa do PMAQ. Rev. Saúde Pública. 2017; 51:67.

12. Instituto Nacional de Câncer José Alencar Gomes da Silva. Estimativa 2018: incidência de câncer no Brasil [internet]. Brasília, DF: Ministério da Saúde. 2017 [acesso em 2018 out 5]; 130 p. Disponível em: https://www.inca.gov.br/sites/ufu.sti.inca.local/files// media/document//estimativa-incidencia-de-cancer-no-brasil-2018.pdf.

13. Instituto Nacional de Câncer José Alencar Gomes da Silva. Atlas On-line de Mortalidade [internet]. Brasília, DF: Ministério da Saúde. [acesso em 2018 jun 9]. Disponível em: https://www.inca.gov.br/MortalidadeWeb/ pages/Modelo03/consultar.xhtml;jsessionid=6F3DE7A 6CAD6C819C044F45E9F2948B3\#panelResultado. 
14. Sistema de Informações sobre Mortalidade. TabNet Win32 3.0: Mortalidade - Brasil [internet]. Brasília, DF: Ministério da Saúde. [acesso em 2018 jun 9]. Disponível em: http://tabnet.datasus.gov.br/cgi/deftohtm.exe?sim/cnv/obtlouf.def.

15. Garcia PT, Reis RS. Gestão pública em saúde: sistemas de informação de apoio à gestão em saúde. São Luís. EDUFMA. 2016; 54 p.

16. Projeção da População das Unidades da Federação por sexo e grupos de idade: 2000-2030. TabNet Win32 3.0: Brasil. Ministério da Saúde. [internet]. [acesso em 2018 jun 18]. Disponível em: http://tabnet.datasus.gov.br/cgi/deftohtm.exe?ibge/cnv/projpopuf.def.

17. Moon EK, Oh CM, Won YJ, et al. Trends and Age-Period-Cohort Effects on the Incidence and Mortality Rate of Cervical Cancer in Korea. Cancer Res Treat. 2017; 49(2):526-533.

18. Ruiz M, Vincent AK, Santos MP. Cervical Cancer Trends in Mexico: Incidence, Mortality and Research Output. Asian Pac. J. Cancer Prev. 2014; 15(20):8689-92.

19. Manica ST, Drachler ML, Teixeira LB, et al. Socioeconomic and regional inequalities of pap smear coverage. Rev. Gaúcha Enferm. 2016; 37(1):1-8.
20. Lin MY, Chennakesavan SK, Bernshaw D, et al. Carcinoma of the cervix in elderly patients treated with radiotherapy: patterns of care and treatment outcomes. Gynecol Oncol. 2016; 27(6):1-11.

21. Yost S, Hoekstra A. Cervical cancer in women over 65: An analysis of screening. Gynecol. Oncol. Rep. 2018; 25:48-51.

22. Benard VB, Watson M, Castle PE, et al. Cervical cancer rates among young females in the United States. Obstet. Gynecol. 2012; 120(5):1117-23.

23. Pelkofsk E, Stine J, Wages NA, et al. Cervical cancer in women aged 35 years and younger. Clin. Ther. 2016; 38(3):459-66.

24. Balmant NV, Reis RS, Santos MO, et al. Trends in cancer mortality among adolescents and young adults in Brazil. J. Adolesc. Young Adult Oncol. 2017; 6(2):341-47.

\footnotetext{
Received on 08/30/2019

Approved on 02/29/2020

Conflict of interests: non-existent

Financial support: non-existent
} 